\title{
A DEVELOPED EXPERT SYSTEM FOR CENTER PIVOT IRRIGATION SYSTEM MANAGEMENT UNDER NEWLY RECLAIMED SOILS OF EGYPT
}

\author{
Mohamed $^{1, *}$ O.M., El-Gindy ${ }^{2}$ A.M. and Mehawed ${ }^{1}$ H.S.
}

1- On-Farm Irrigation Engineering Dept., Agric. Eng. Research Institute, ARC, Giza, Egypt

2- Agric. Engineering Dept., Fac. of Agric., Ain Shams Univ., P.O. Box 68-Hadayek Shoubra 11241, Cairo, Egypt

${ }^{*}$ Corresponding author: osamamobarakmohamed@gamil.com

\section{ABSTRACT}

Accurately estimation of actual crop evapotranspiration $\left(E T_{a}\right)$ as a parameter of irrigation scheduling is very critical for efficient use of limited irrigation water resources. The objectives of this study were to (1) build, verify and validate an expert system for managing on-farm irrigation water of some soils under Egyptian conditions, (2) study the effect of coefficient of uniformity (CU) and distribution uniformity for center pivot irrigation system, (3) study the effect of the precise estimation of daily actual crop evapotranspiration (ETa) on maximizing yield and improved water use efficiency.

A rule-based program named CPISM-ES (Center Pivot Irrigation System Management- Expert System) was codes and compiled using python3.7.2 language. The program was verified using ready-to-use software programs (cropwat-8 and climwat 2) for estimating the daily reference evapotranspiration and a spreadsheet named the (FAO56Ax8.xls) introduced by FAO-56 for estimating the irrigation water management parameters. It also was validated by carrying out a field experiment at site :-El Salhyia(11.2 m above sea level, $30,35^{\circ} \mathrm{N}, 30,26^{\circ} \mathrm{E}$ ), was obtained from several different sources. The irrigation expert system aims to provide the farmers by the irrigation expertise to determine the exact water needed at exact time according to the crop requirements and the environmental factors which effect factors. The experiment included the following factors: a) obtaining climatic data from a weather station b) estimation crop evapotranspiration) coefficient of uniformity (CU) and distribution uniformity for center pivot irrigation system.
1- The estimation of actual crop evapotranspiration $\left(E T_{a}\right)$ using crop coefficient.

2- The seasonal cumulative $\mathrm{ET}_{\mathrm{a}}$ estimated by single- $k_{c}$ approach of El Salhyia $\left(1875 \mathrm{~m}^{3} \mathrm{f}\right.$. ${ }^{1}$ season $^{-1}$ ).

3- Yield: the highest of crop potatoes for El Salhyia $\left(16.2\right.$ t.fed $\left.^{-1}\right)$.

4- Water use efficiency: the maximum value of water use efficiency for El Salhyia $\left(0.75 \mathrm{~kg} \mathrm{~m}^{-3}\right)$.

Keywords: El-Salhyia, Evapotranspiration, Potatoes, Climwat 2

\section{1- INTRODUCTION}

Variable rate irrigation (VRI) systems are irrigation systems that are capable of applying different water depths both in the direction of travel and along the length of the irrigation system. Spatial water applications attempt to overcome sitespecific problems that include spatial variability in topography, soil type, soil water availability, and landscape features but may also be used in response to site-specific crop water requirements. VRI systems are commercially available and have high grower interest. Center pivots with VRI systems have typically been managed for precision irrigation applications based on either the producers' past experience and knowledge of variability in their fields or by using other static parameters. The USDA-ARS National Peanut Laboratory in Dawson, Georgia, has developed and distributed an expert system (Irrigator Pro) for corn management (Davidson et al 1998). Irrigator Pro assists producers with irrigation management by integrating 
several factors, including soil type, cultivar, and planting date. During the growing season, the expert system requires inputs of rainfall and soil water potentials to recommend a decision on when and how much to irrigate depending on the upcoming 3 to 5 day rainfall probabilities. Another method of estimating irrigation requirements is the FAO-56 method (Allen et al 1998), in which crop coefficients are used for determining the irrigation requirement of a crop over the growing season using reference evapotranspiration (ETo) measurements. The FAO-56 method provides standard generalized estimates of the crop coefficients that may not be appropriate for every location, and it does not readily lend itself to $\mathrm{VRI}$ management. A potential method to estimate spatial crop coefficients is using remotely sensed canopy reflectance (Gao et al 2014). In the past decades, water resources scarcity is getting more and more serious due to growing population, developing economy, varying natural condition, shrinking water availability, and deteriorating water quality. Irrigation water management is crucial for agricultural production and livelihood security in many regions and countries throughout the world (Storm et al 2011). Efficient irrigation management is very critical for improving water use efficiency as well as maximizing yield to face the increasing demands on limited water resources (Patel and Rajput, 2008). Irrigation scheduling is a method of applying water for irrigation of crops based on calculated crop water needs. It improves water management while maximizing crop yields. Modeling and simulation of irrigation has been employed in many regions, and a number of irrigation schedules have been developed (Grassini et al 2011).

Expert systems can offer a good solution for management irrigation water due to the rarein irrigation experts and difficulties in finding them. It transfers expertise to farmers helping them to irrigate their crops in the same way the irrigation experts done, Ayman et al (2014). Optimize the irrigation water usage need an expert to provide farmers by the exact needed water at exact time to irrigate their crops. These experts are rare to found when farmers needed. Also, it doesn't easy to found them in all Egypt villages. Using information and communication technology to develop systems that manage water usage will help in enhancing the irrigation water usage efficiency. Expert systems technology can be used to transfer knowledge from irrigation experts to both agricultural engineers/officers and farmers which lead to enhance water usage in Egypt. Expert system also known as knowledge based system which is a branch of artificial intelligence and was developed by the Al community in the mind-1960s, Karagamz et al (2007). It is a computer program that includes the knowledge and analytical skills of one or more human experts in a particular problem domain, Tripathi (2011). The idea of expert system building is to code knowledge in to a computer program so it can be consulted in much the same way that one consults a human expert. Well-designed expert systems mimic the human experts reasoning process to solve specific problems and can be used by non-experts to improve their problem-solving capabilities. Also, experts can use it as knowledgeable assistants, Gutierrz (2005). The use of expert systems technology has many benefits. It was explained through experiments where the fields which are managed by the expert system have used less resource in terms of pesticides, fertilizers and water than the control fields and preserve environment, Mahmoud et al (2001). Also, the expert systems training courses increase the knowledge base of extension agents and speed the introduction of new technologies and agronomic practices, Rafea and Sallan (1996). The goal of the work described here is to optimize crop water usage by using expert system technology. This goal can be achieved by helping framers to irrigate their crops by the exact needed amount of water at the exact needed time.

\section{2- MATERIALS AND METHODS}

\subsection{Irrigation model}

\section{1) Building up CPISM-ES program}

A rule-based program named CPISM-ES (Center Pivot Irrigation System Management- Expert System) was coded and compiled using python3.7.2 language and contains many new features and optimizations. The schematic overview showing the key input and output processing and main computational steps needed for the CPISM-ESrulebased program is shown in Fig. (1). The following sections outline how the program CPISM-ES was built. 

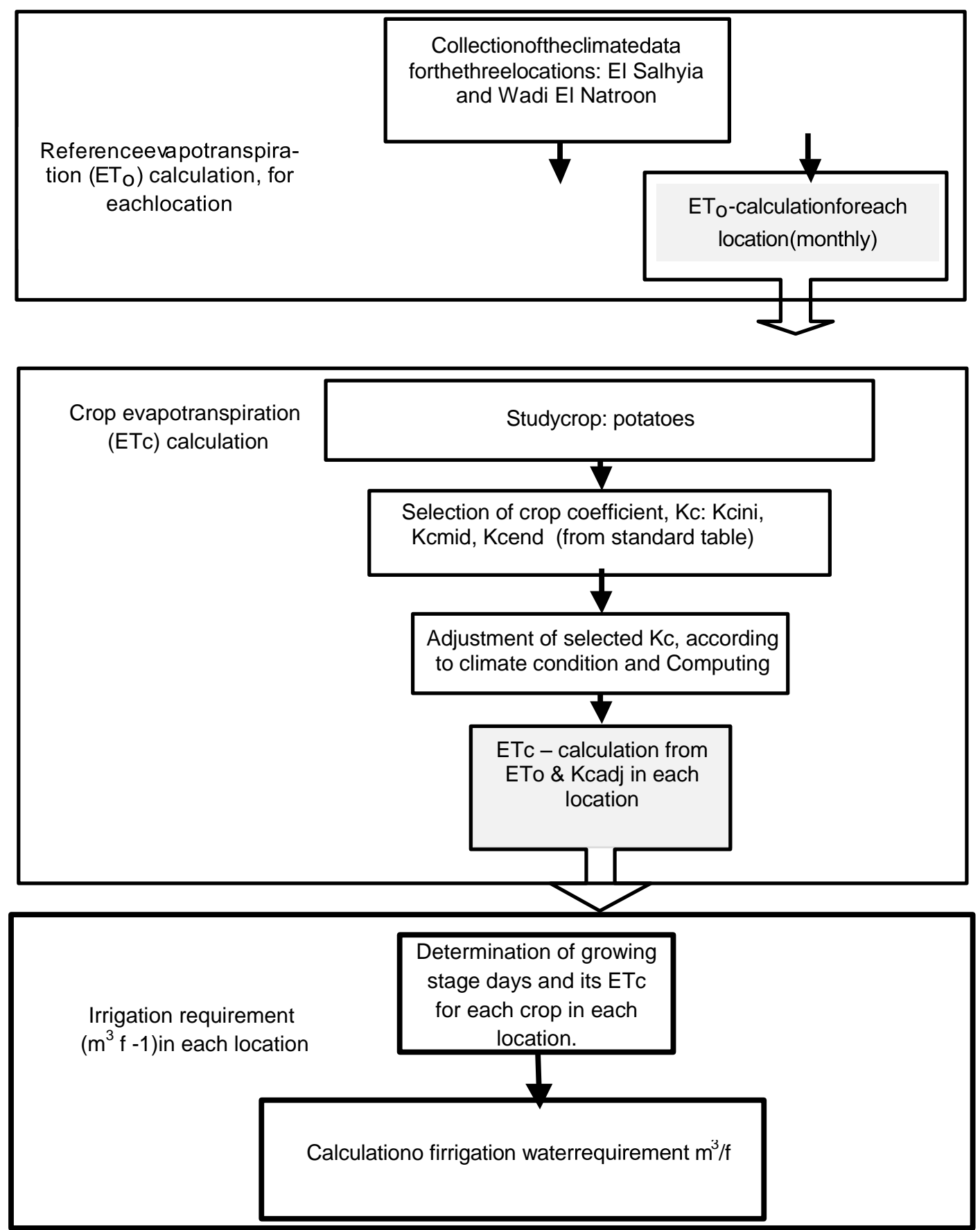

Fig. 1. Process schema of method of calculating the irrigation water demand

\section{2) User interface}

A graphic user interface (GUI) is designed to have a clear and soft feel to advance easy use for both experienced users and novice as farmers and support them with decision-making related to irrigation water management easily.

\section{3) Structure of CPISM-ES}

The structure of the CPISM-ESrule-based program was designed to produce an irrigation schedule over a whole season. The structure of the program consisted the two following sections: 


\section{- Conceptualization}

The concept properties are represented as object attributes. The property facts depend on the property value, type and source from which the program gets the property value. All concepts as entries step-by-step building up of reference evapotranspiration (ETo), crop evapotranspiration $\left(E T_{a}\right)$ using single- $\mathrm{k}_{\mathrm{c}}$ and irrigation requirements.

\section{- Formalization}

The parameters such as: (ETo, $E T_{a}, k_{c}$, and IR) were considered to calculate the irrigation scheduling. These parameters considered in this study depended on a number of factors and rules.

Using specific equation the parameters could be estimated. Some equations should be put in the form of rules as shown in Fig. (2).

\section{4) Database}

The database consists of the climatic data of the experimental sites.

The system prompts the user crop type; potato. The inputs comprising

1- Climatologic data (average air temperature (t-mean), average relative humidity (rh-mean); average wind speed (mean um); average daily sunshine (nhr); daily extraterrestrial radiation (ra) and max. daylight (ntable).

2- Location (El Salhyia) (Some reference soil physical properties in El-Salhyia in Table (1).

3- EvapotranspirationEto (Penman-Monteith).

4- Crop Coefficient $\mathrm{K}_{\mathrm{c}}$ (single Crop Coefficient)

5- Center Pivot

6- Calibration

7- Management

\section{Outputs required}

1- ETc

2- Irrigation requirement

3- Irrigation intervals

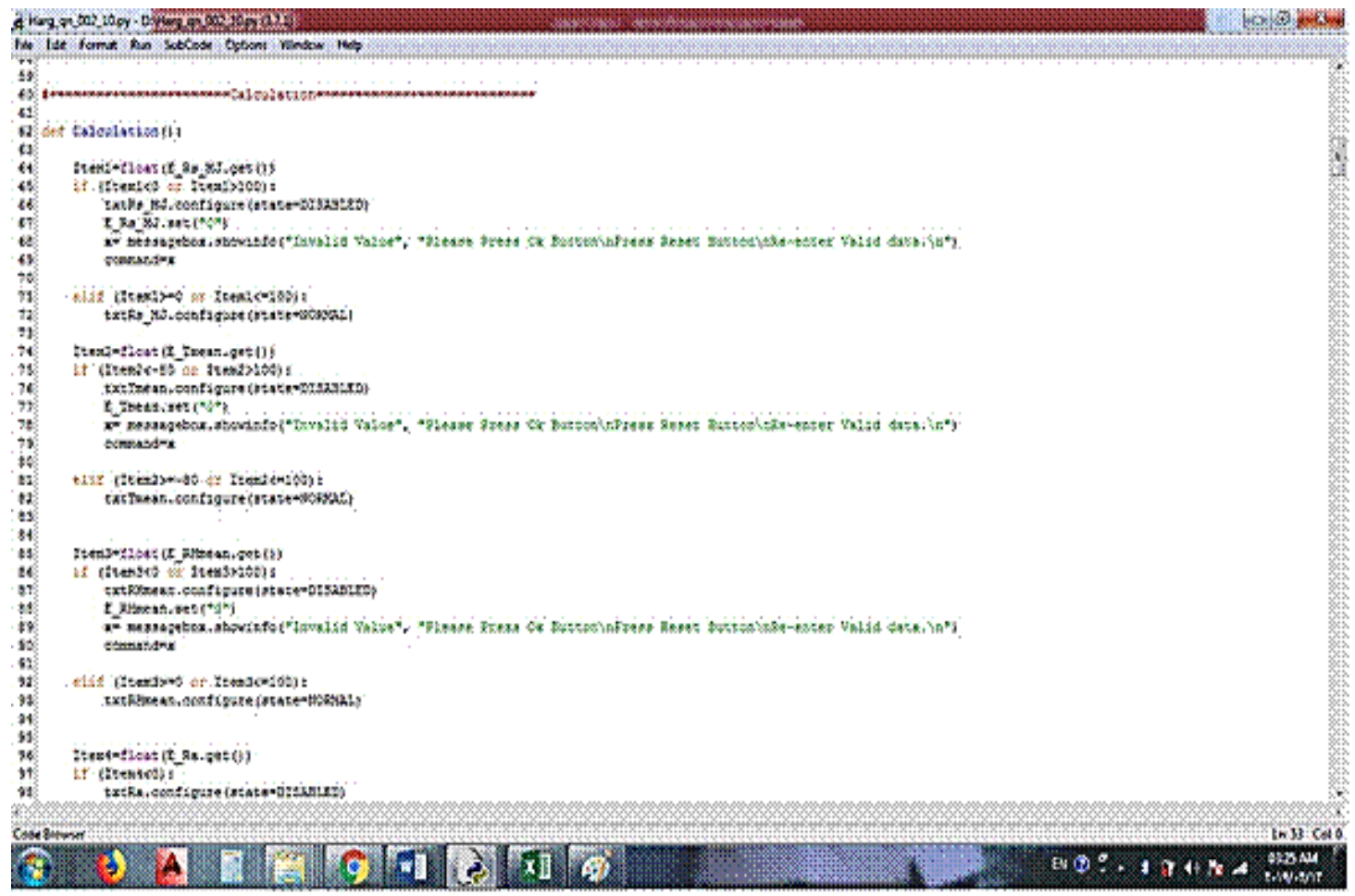

Fig. 2. Program-Code for calculating reference evapotranspiration according to process in Figure 2, by python-3.7.2-amd64 


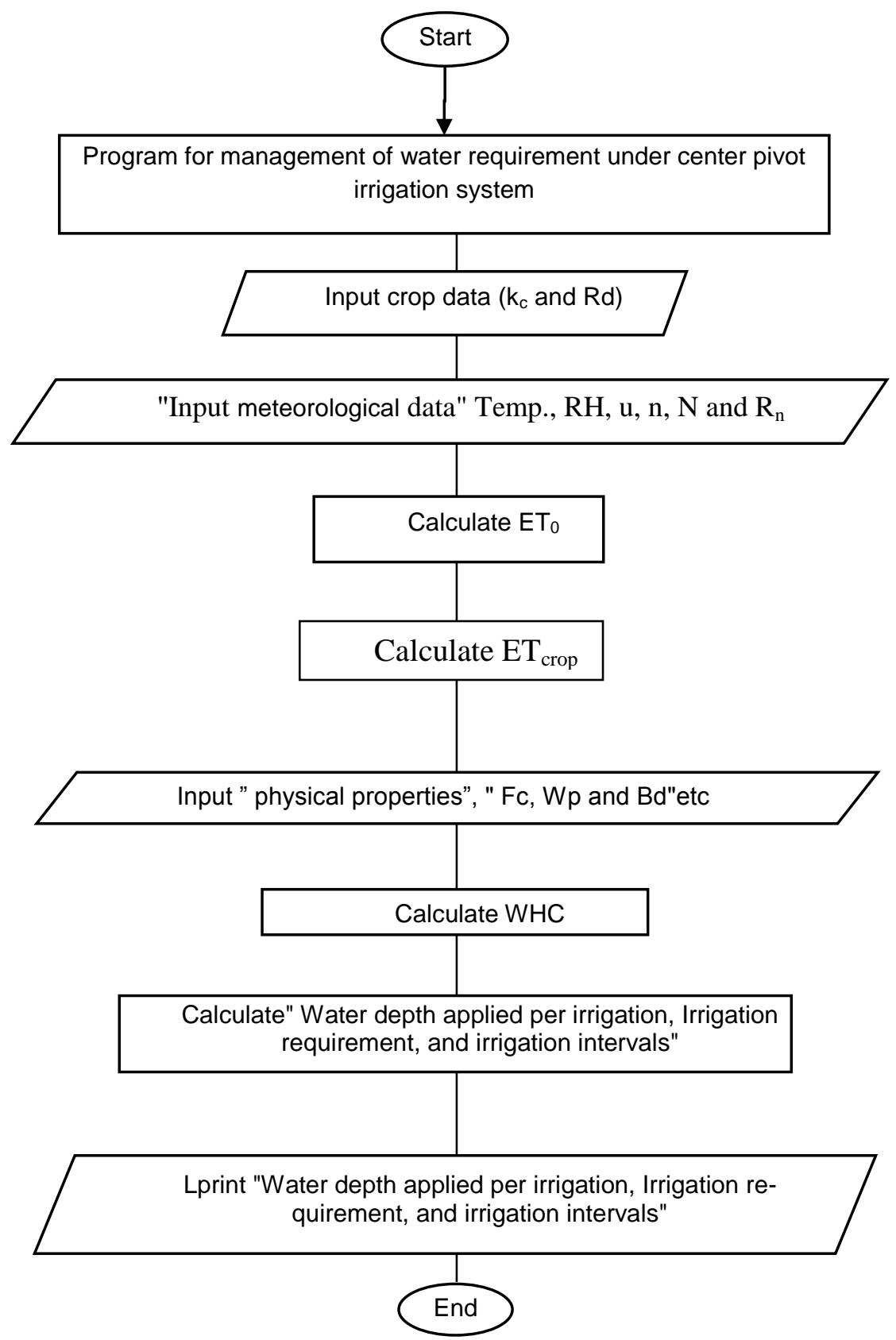

Fig. 3. Flow chart components of proposed program for management of water requirement

Table 1. Some reference soil physical properties in El Salhyia site (present study).

\begin{tabular}{|c|c|c|c|c|c|c|c|c|c|}
\hline $\begin{array}{c}\text { Sample } \\
\text { depth } \\
\text { (cm) }\end{array}$ & \begin{tabular}{c} 
Particle size distribution (\%) \\
\cline { 2 - 5 }
\end{tabular} & $\begin{array}{c}\text { Coarse } \\
\text { Sand }\end{array}$ & $\begin{array}{c}\text { Fine } \\
\text { Sand }\end{array}$ & Silt & Clay & $\begin{array}{c}\text { WP } \\
(\%)\end{array}$ & $\begin{array}{c}\text { Bd } \\
\left(\mathbf{9} / \mathbf{c m}^{3}\right)\end{array}$ & $\begin{array}{c}\text { WHC } \\
(\mathbf{m m} / \mathbf{m})\end{array}$ & $\begin{array}{c}\text { Texture } \\
\text { class }\end{array}$ \\
\hline \multicolumn{8}{|c|}{ ii) El salhyia site: } \\
\hline $\mathbf{0 - 3 0}$ & 52.8 & 41.4 & 4.1 & 1.7 & 9.4 & 4.3 & 1.7 & 86.7 & $\mathrm{~S}$ \\
$\mathbf{3 0 - 6 0}$ & 50.0 & 43.5 & 5.0 & 1.5 & 8.5 & 4.4 & 1.6 & 65.6 & $\mathrm{~S}$ \\
\hline
\end{tabular}

$F C=$ field capacity; $W P=$ welting point, $F C$ and $W P$ were determined as percentage in weight; $B d=$ bulk density; $W H C=$ water holding capacity; $S=$ sand. 
Center pivot sprinkler irrigation systems Description

Tables 2 and $\mathbf{3}$ and Fig. 4 show that the Center pivot sprinkler irrigation system is used in
El-Salhyia to irrigate potato. Center pivot system in consist of 8 towers. Lengths of the towers $56 \mathrm{~m}$ and numbers of sprinklers are different from one tower.

Table 2. Description Center pivot sprinkler irrigation system in El Salhyia

\begin{tabular}{|c|c|c|c|c|c|}
\hline Span & Span length, $\mathbf{m}$ & $\mathbf{R}^{\mathbf{2}}$ & Span Flow $\left(\mathbf{m}^{\mathbf{3}} \mathbf{h}^{-1}\right)$ & Sprinkler & Averge Sprinkler Flow $\left(\mathbf{m}^{\mathbf{3}} \mathbf{h}^{-1}\right)$ \\
\hline 1 & 57.4 & 3294.76 & 5 & 16 & 0.3 \\
2 & 56.1 & 12882.25 & 15.3 & 19 & 0.8 \\
3 & 56.1 & 28764.16 & 24.1 & 18 & 1.3 \\
4 & 56.1 & 50940.49 & 35.5 & 19 & 1.9 \\
5 & 56.1 & 79411.24 & 43.2 & 18 & 2.4 \\
6 & 56.1 & 114176.41 & 54.8 & 19 & 2.9 \\
7 & 56.1 & 155236 & 64 & 36 & 1.8 \\
8 & 56.1 & 202590.01 & 73 & 37 & 2.0 \\
\hline
\end{tabular}

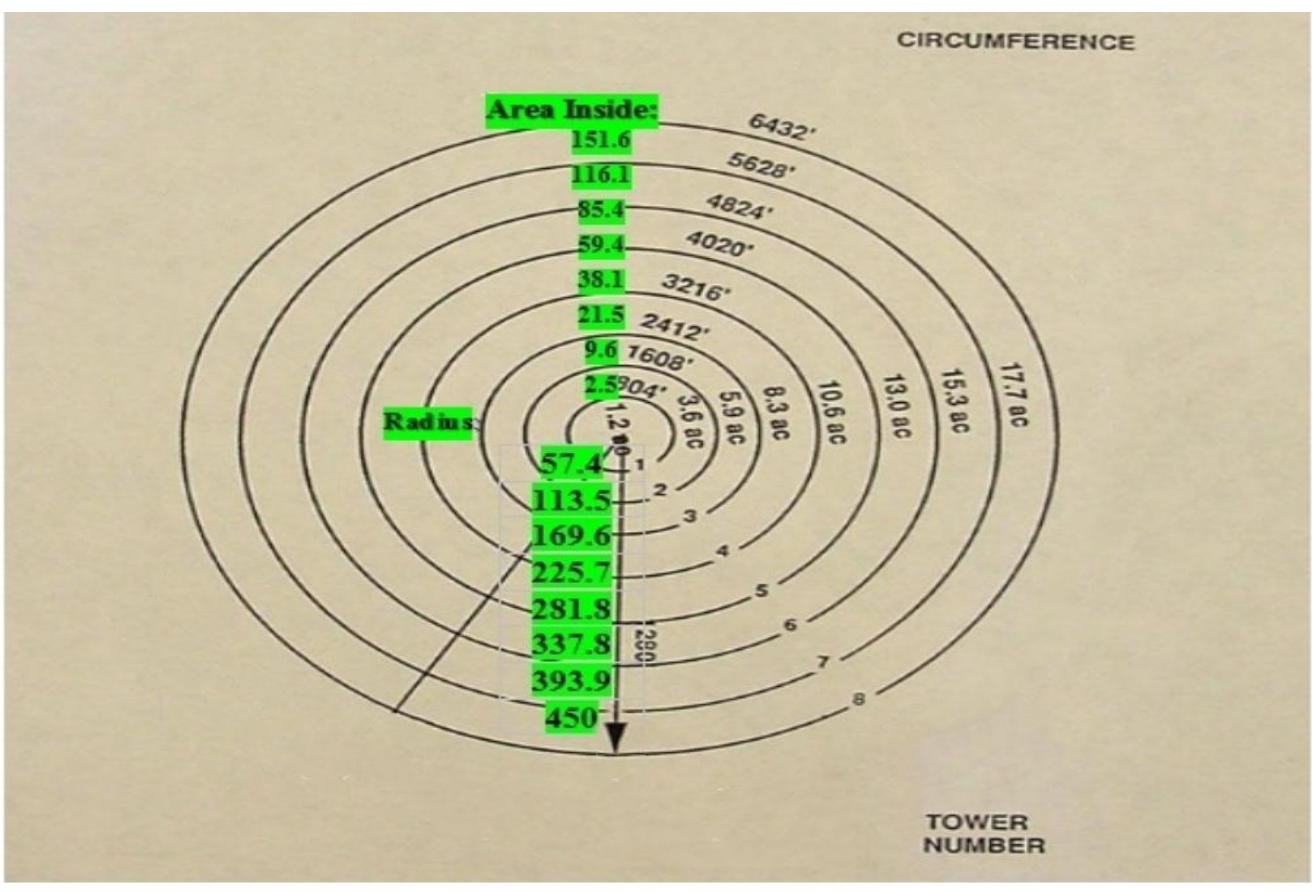

Fig. 4. Area covered by each sprinkler increases as the distance from pivot center increases. 
Table 3. The properties for center pivot system

\begin{tabular}{|c|c|c|c|}
\hline Timer Setting \% & $\begin{array}{c}\text { Water Application on } \\
\text { Irrigated Area (mm) }\end{array}$ & Time per $\mathbf{3 6 0} \mathbf{( h r s )}$ & $\begin{array}{c}\text { LRT Last Tower Ground } \\
\text { Speed (m/min) }\end{array}$ \\
\hline 100 & 5.7 & 11.6 & 4.08 \\
80 & 7.1 & 14.4 & 3.26 \\
70 & 8.2 & 16.5 & 2.86 \\
60 & 9.5 & 19.3 & 2.45 \\
50 & 11.4 & 23.1 & 2.04 \\
40 & 14.3 & 28.9 & 1.63 \\
30 & 19.1 & 38.5 & 1.22 \\
20 & 28.6 & 57.8 & 0.82 \\
15 & 38.1 & 77 & 0.61 \\
10 & 57.2 & 115.5 & 0.41 \\
8 & 71.4 & 144.4 & 0.33 \\
6 & 95.3 & 192.5 & 0.24 \\
5 & 114.3 & 231 & 0.2 \\
\hline
\end{tabular}

Reference-Evapotranspiration, Crop Evapotranspiration and Irrigation Requirements Reference- Evapotranspiration (ETo).

\section{Penman-Monteith Equation}

Evapotranspiration from meteorological data was estimated using the following equation (Allen et al 1998) comprising a number of climatological and physical variables:

Reference evapotranspiration, ETo (Pereira et al 1996). In the current investigation we will use the concept of reference evapotranspiration (ETO) which has been defined as the rate of evapotranspiration from a hypothetical reference crop. For calculation of (actual) crop evapotranspiration $\left(E T_{c}\right)$, the crop coefficient $\left(K_{c}\right)$ that acts as an aggregation of the physical and physiological difference between crops must be available in addition to the reference evapotranspiration (ETO). Actual crop evapotranspiration can be calculated by multiplication $\mathrm{K}_{\mathrm{c}}$.

The first is given by the reference evapotranspiration $\mathrm{ET}_{0}$ and the second is given by the crop coefficient $\mathrm{K}_{\mathrm{c}}$, which represents the relationship between $\mathrm{ET}_{\mathrm{O}}$ and $\mathrm{ET}_{\mathrm{C}}$, (Doorenbos and Pruitt, 1977).

The crop coefficient, $\mathrm{K}_{\mathrm{c}}$, is basically the ratio of the crop evapotranspiration to the reference evapotranspiration, and it represents an integration of the effects of four primary characteristics that distinguish the crop from reference grass" (Achtnich, 1980).

\subsection{Methodology and Equations to calculate the Coefficient of Uniformity}

Modified Heermann and Hein formula will be used (1) to calculate the Coefficient of Uniformity (CU).

\section{Distribution Uniformity (DU1/4)}

DU 1/4 measures the driest lower quarter applied to the field and compares it to the entire catch. In order to determine whether the system is operating at acceptable efficiency, DU (of low quarter) will be calculated using equation.

The average weighted system catch (Ave. W $\mathrm{gt}$ ) is found (4) by dividing the sum of the weighted catches by the sum of the catch location where cups are placed. For the average minimum weighted catch (Ave. W gt low), an unknown number of cups that represents the low $1 / 4$ of the irrigated area must be used. The low $1 / 4$ is selected by picking progressively larger (unweight) catches and keeping a running total of the associated location until the subtotal approximately $1 / 4$ of the sum of all the catch location. The average weighted low $1 / 4$ of the catch is then found by dividing the sum of the DU $1 / 4$ of the weighted catches by the sum of the associated catch location. 
Calibration values calculated in the present study Table 4 for irrigation system were used for calculating the equations related to water application efficiency.

\section{Water Use Efficiency (WUE)}

The overall agronomic efficiency of water use, WUEag, can be expressed as (Hillel et al1998).

\section{RESULTS AND DISCUSSION}

\section{Comparison of evapotranspiration models}

Table 4 and Figs. 5 and 6 show that the reference evapotranspiration over the year was determined for the one research site using the model for calculating reference evapotranspiration.
The model itself was compared to the results obtained by weather station and climwat 2.0 from calculations using various other evaporation models. On the basis of field measurements of actual evapotranspiration, that no single method, in their view, was able to establish correctly the reference evapotranspiration over the course of the whole vegetation cycle. Conversely, the annual $\mathrm{ET}_{0}$ lines determined solely by the present model showed only a slight deviation from the mean values established by weather station

ETo-Model-values in comparison to CLIMWATvalues

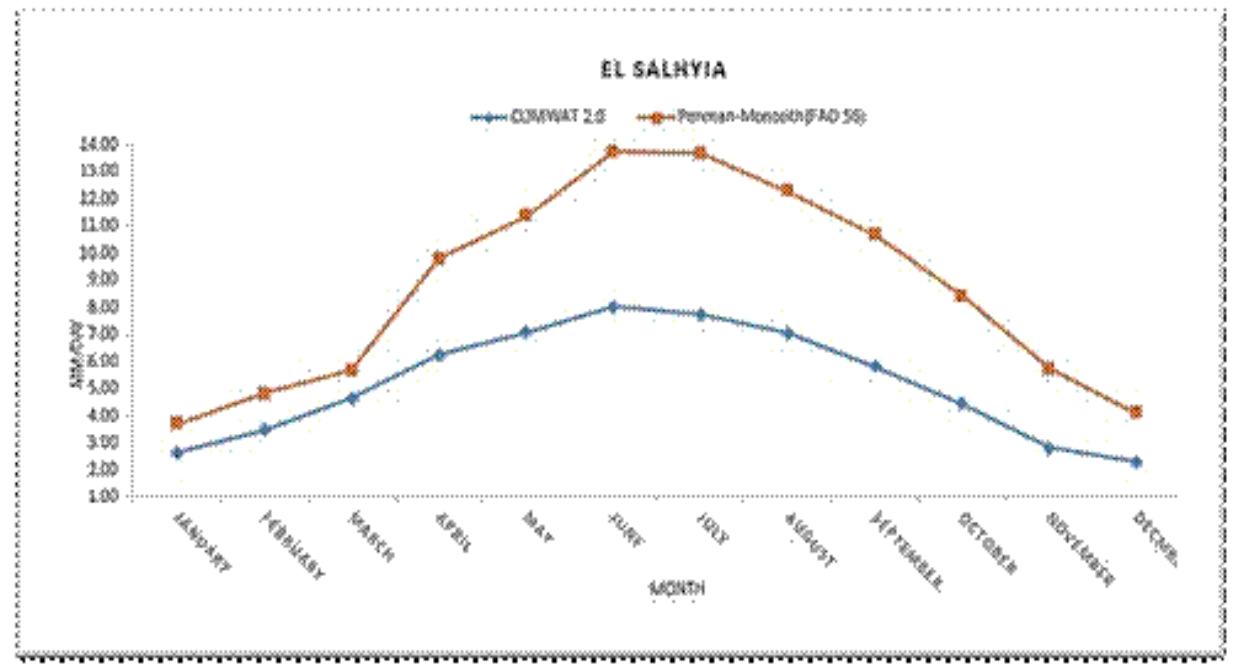

Fig. 5. Comparison between $\mathrm{ET}_{0}$-model-values and the values of CLIMWAT for ErSalhyia. The correlation coefficient $(r)$ between the model-values and CLIMWAT-values was: $r=0.966$

\section{Calculation of irrigation water requirements (calculation and results)}

Calculation of the irrigation water requirement for the research locations followed the procedure described in Fig. (3).

1. First of all, the climatic data for the one station El Salhyia was compiled mean monthly value for temperature, relative humidity, wind velocity, actual hours of sunshine, maximum possible hours of sunshine, radiation.

2. For each research location, the reference evapotranspiration was calculated by the methods Penman-Monteith Equation and Hargreaves Equation, and climatic data. These calculations were carried out with a model (see Fig. 6) developed using the programming lan- guage python-3.7.2-amd64. In this model the data can be entered in a comparatively simple way. The resulting $\mathrm{ET}_{0}$ values are listed by district in Table (4).

Calculation of the irrigation water requirements was carried out for commercially important crop namely potatoes.

The plant water consumption (crop evapotranspiration $\mathrm{ET}_{\mathrm{C}}$ ) was calculated for each crop according to Equation 2. As the standardized crop coefficients ( $\mathrm{K}_{\mathrm{C}}$ values) of the FAO (Table 4 and Figs. 7 and 8 ) are valid only for semi-humid conditions $\left(\mathrm{RH}_{\min } \sim 45 \%\right.$ and wind velocity $\left.2 \mathrm{~m} \mathrm{~s}^{-1}\right)$, the crop coefficient must be adjusted as recommended by ASCE (1996); Neale et al (1996) and Allen et al (1998). 


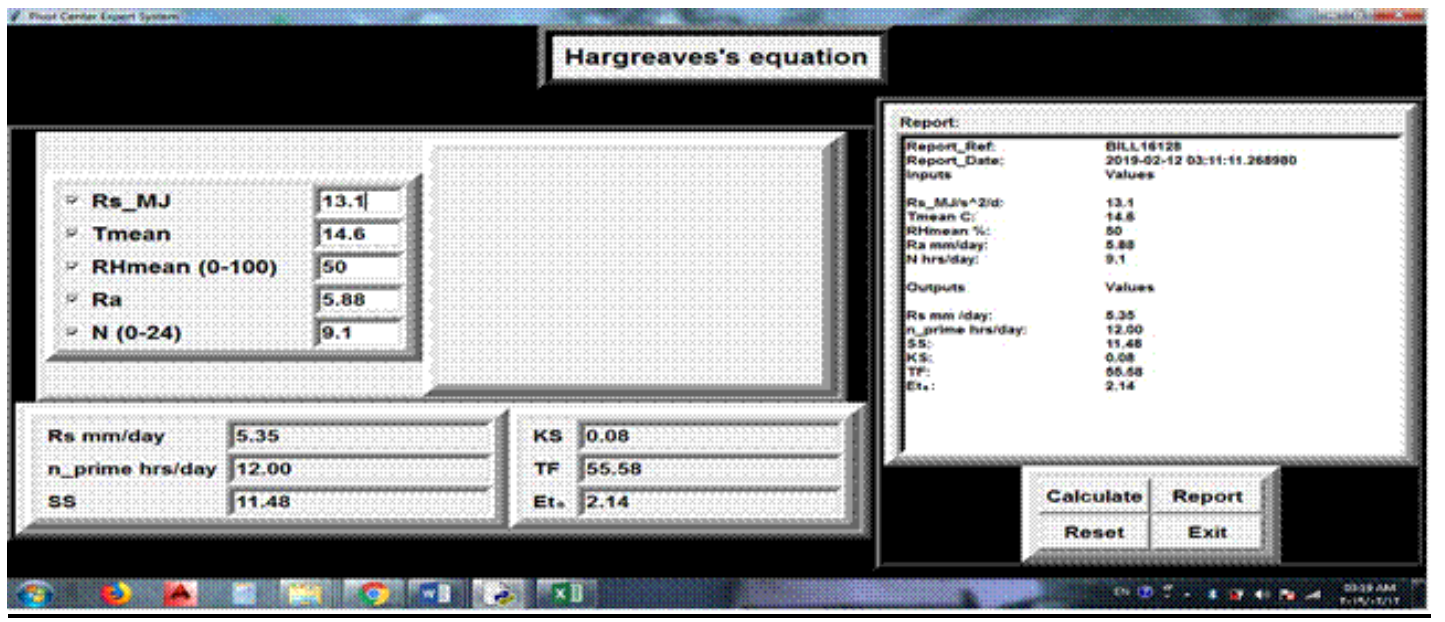

Fig. 6. Program-Execute for calculating reference evapotranspiration will be calculated instead of cropevapotranspiration

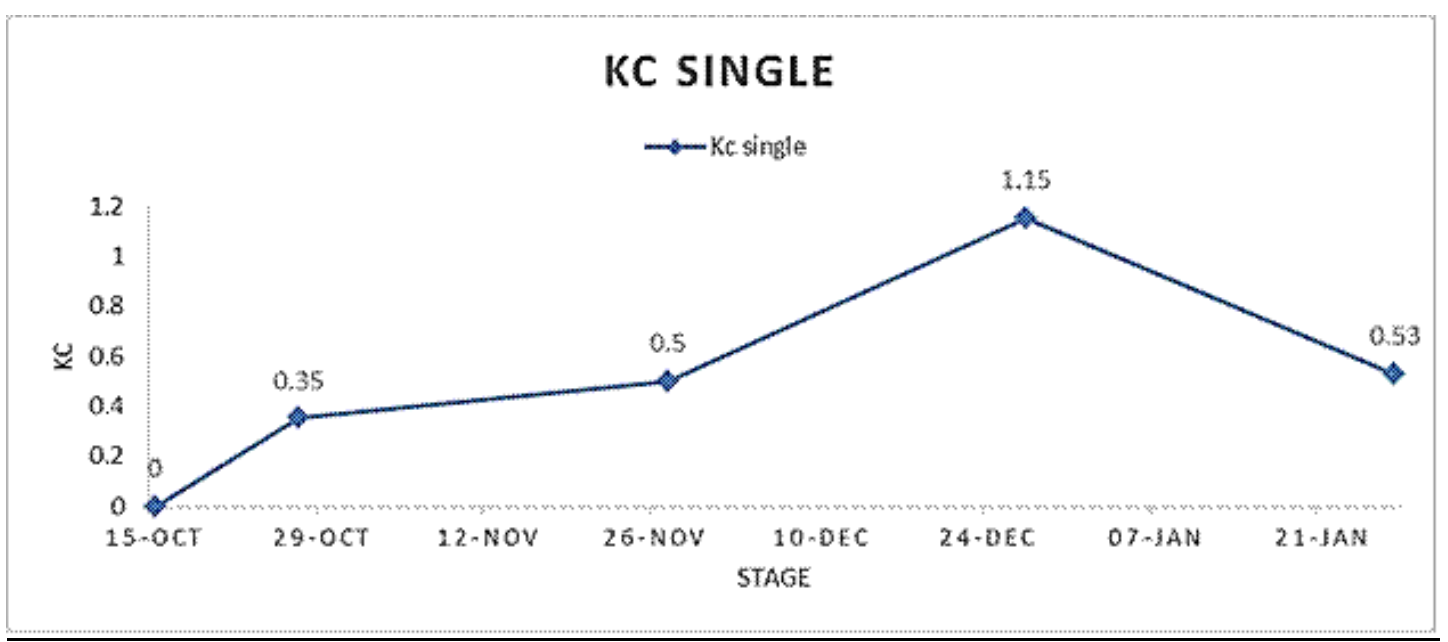

Fig. 7. Single (time average) crop coefficients $\left(\mathrm{K}_{\mathrm{c}}\right)$

Table 4. Calculated $\mathrm{ET}_{\mathrm{C}}$-values $\left(\mathrm{mm} \mathrm{m}^{-1}\right)$ (plant water requirement) for research crop

\begin{tabular}{|c|c|c|c|c|c|c|}
\hline Planting Date & \multicolumn{2}{|c|}{$18 / 10 / 2017$} & Harvesting Date & \multicolumn{2}{|c|}{$30 / 01 / 2017$} & \\
\hline location & \begin{tabular}{|l|} 
El Salhyia \\
\end{tabular} & & & & & \\
\hline & & & CLIMWAT 2.0 & $\begin{array}{c}\text { Penman- } \\
\text { Monteith (FAO } \\
56)\end{array}$ & & \\
\hline Stage & Month & Kc single & EtoCropwat & Eto CPISM-ES & Etccropwat & $\begin{array}{c}\text { Etc } \\
\text { CPISM-ES }\end{array}$ \\
\hline initial stage & October & 0.35 & 1.56 & 2.95 & 0.55 & 1.03 \\
\hline crop dev. Stage & November & 0.5 & 1.41 & 2.87 & 0.71 & 1.44 \\
\hline mid season stage & December & 1.15 & 2.66 & 4.70 & 3.05 & 5.41 \\
\hline late season stage & January & 0.53 & 1.40 & 1.96 & 0.74 & 1.04 \\
\hline
\end{tabular}




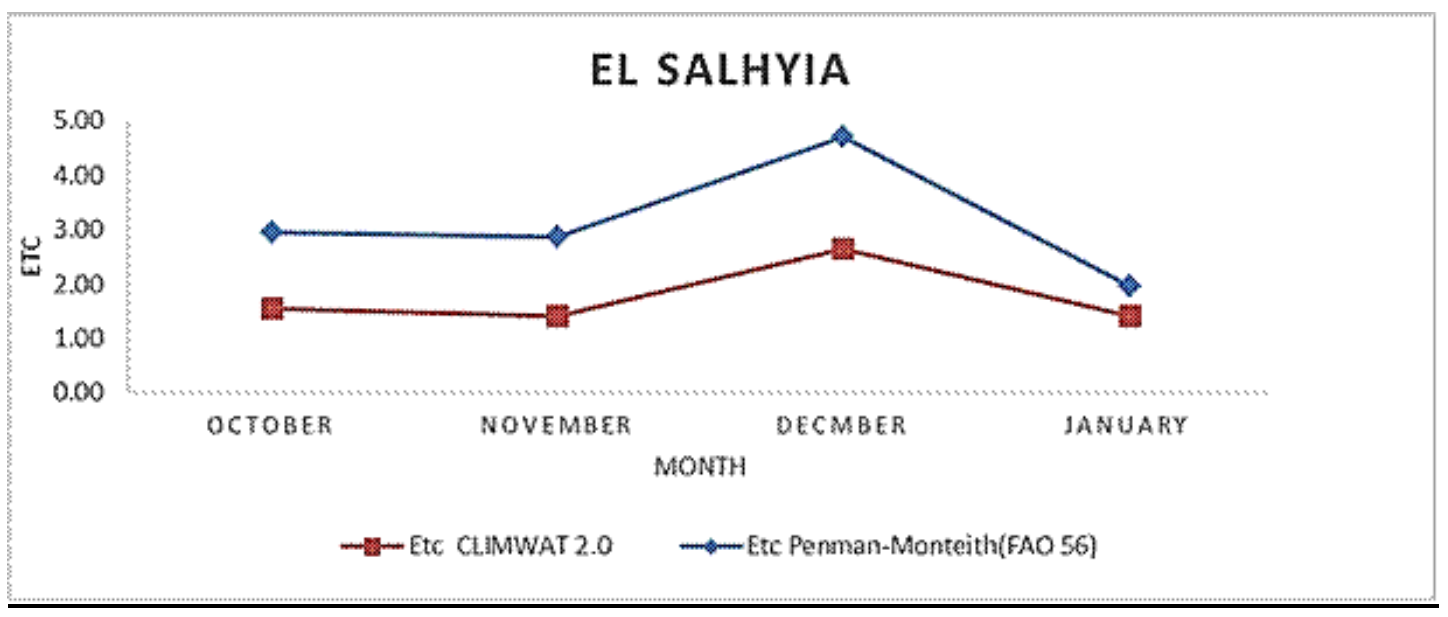

Fig. 8. Calculated $\mathrm{ET}_{\mathrm{C}}$-values

\section{Coefficient of Uniformity (CU) and Distribution Uniformity}

Uniformity of a system is a measure of its ability to apply the same depth of water to every unit area. Without good uniformity, it is impossible to irrigate adequately and efficiently; parts of the field will be either over-irrigated or under-irrigated. Three uniformity measurements are to be considered in the evaluation; Coefficient of Uniformity (CU) and Distribution Uniformity (DU) and Potential Application Efficiency of Low Quarter (PELQ). A CU rating of $90 \%-95 \%$ is considered excellent and would on lyre quire regular maintenance. $85 \%-90 \%$ is considered good and would not need major adjustments; regular maintenance and inspection are required. $80 \%-85 \%$ the system requires inspection and sprinkler package check. $80 \%$ orless the system requires an adjustment to the sprinkler package, change the default system, sprinkle pressure and conduct full maintenance for the whole system. The CU accounts for the increased area covered by each sprinkler as you move further from the pivot center. DU compares the lowest quarter of the water depth caught to the entries et of data from the catch cans. DU is useful as an indicator of the magnitude of the distribution problems. DU is calculated by dividing the weighted average of the lowest $25 \%$ of the catch cans by the weighted average of the entire catch cans. A DU of $85 \%$ or greater is considered excellent, $80 \%$ is considered verygood,75\%is considered good, $70 \%$ is considered fair, and $65 \%$ or less is considered poor and unacceptable (Table 5).

Potential Application Efficiency of Low Quarter (PELQ) is a measure of how well the system can apply water if management is optimal. PELQ is the ratio of the lowest $25 \%$ weighted average depth in the catch cans to the average applied rate that is obtained from the flow rate, revolution time, and wetted area. In this way deep percolation losses would be kept to minimum (3). Low values Indicate design or management problems.

Table 5. Calibration values (present study) for irrigation system

\begin{tabular}{|c|c|c|}
\hline Irrigation system & Calculation characteristic & Values obtained \\
\hline \multirow{6}{*}{ Center pivot irrigation } & Mean depth of observations $(\mathrm{m})(\mathrm{mm})$ & 8.0 \\
\hline & $\begin{array}{l}\text { Sum of absolute deviations of individual observations } \\
\text { from the mean }(\mathrm{mm})\end{array}$ & 35.1 \\
\hline & Number of observations (n) & 21 \\
\hline & Average of lowest the quarter of water received ) (a) (mm) & 6.2 \\
\hline & Coefficient of uniformity (CU) (\%) & 80 \\
\hline & Distribution of uniformity (DU) (\%) & 78 \\
\hline
\end{tabular}


Water Use Efficiency (WUE)

Water Use Efficiency (WUE) reflects on how well the water is used in producing crops.
WUE is by no means an engineering term, because WUE depends on so many factors and involves so many biophysical processes that are beyond the scope of engineering field Table (6).

Table 6. Water use efficiency (WUE)

\begin{tabular}{|c|c|c|c|}
\hline Location & $\begin{array}{c}\text { The crop production } \\
\mathbf{t ~ f e d . ~}^{-1}\end{array}$ & $\begin{array}{c}\text { The volume of water applied } \\
\left(\mathbf{m}^{\mathbf{3}} \mathbf{f .}^{-1} \mathbf{s e a s o n}^{-1}\right)\end{array}$ & Water Use Efficiency \\
\hline El Salhyia & 16.2 & 1875 & 0.75 \\
\hline
\end{tabular}

\section{REFERENCES}

Achtnic W. 1980. Bewässerungsl andbau: Agrotechnische Grundlagender Bewässerungs wirtschaft. Verlag Eugen Ulmer Stuttgart.

Allen R.G., Pereira L.S., Raes D. and Smith M. 1998. Crop evapotranspiration; Guidelines for computing crop water requirements. FAO, irrigation and drainage, Rome, $56 \mathbf{p}$.

ASCE American Society of Civil Engineers 1996. Hydrology Hand book. ASCE Manuals and Reports on Engineering Practice No. 28. Publishedby ASCE. 345 East $47^{\text {th }}$ St., New York. USA. pp. 255-258.

Ayman N., Mona N. and Hazman M. 2014. Irrigation Expert System for Trees. Int. J. of Eng and Innovative Technology, 3(8), 170-175.

Davidson J.I.Jr, Griffin W.J., Lamb M.C., Williams R.G. and Sullivan G. 1998. Validation of EXNUT for scheduling peanut irrigation in North Carolina. Peanut Sci. 25, 50-58.

Doorenbos J. and Pruitt W.O. 1977. Crop water requirements Irrigation and drain age. PaperNo. 24. Food and Agric. Organization of the United Nations. FAO, Rome, Italy. 144 p.

Gao Y., Duan A., Qiu X., Li, X., Pauline U., Sun J. and Wang H. 2014. Winter wheat with subsurface drip irrigation (SDI): Crop coefficients, water-use estimates, and effects of SDI on grain yield and water use. Agric. Water Management, 146, 1-10.

Grassini P., Thorburn J., Burr C. and Cassman K.G. 2011. High-yield irrigated maize in the Western U.S. corn Belt: I. On-farm yield potential, and impact of agronomic practices. Field Crops Research, 120(1), 142-150.

Gutierrez-Estrada J.C., De Pedro San E., Luquec R. and Pulido-Calvo I. 2005. "SEDPA: an expert system for disease diagnosis in eel rearing systems," Aqua cultural Eng., 33, 110-125.

Hillel D. 1998. Environmental Soil Physics. Academics Press, London, UK, 771 p.
Karagamz St., Dounis A.I. Chalastras T. Tiropanis P. and Papachristos D. 2007. " Design of Expert System for Search Allergy and Selection of the Skin Tests using CLIPS," Int. J. of Information and Communication Eng., 3, 378-381.

Mahmoud M., Rafea M. and Rafea A. 2001. "The evaluation and impact of NEPER wheat expert system," proceeding of AIA'2001 IFAC/CIGR Fourth Int. Workshop on Artificial Intelligence in Agric., June 6-8. pp. 25-29.

Neale C.M.M., Ahmed R.H., Moran M.S., Pinter P.J., JiaGuo Qi, Clarke T.R., Qi J.G., Camp C.R., Sadler E.J. and Yoder R.E. 1996. Estimating seasonal cotton evapotranspiration using canopy reflectance. Evapotranspiration and irrigation scheduling. Proceedings of the international conference.San Antonio, Texas, USA, No vember 3-6. 173-181.

Patel N. and Rajput T.B.S. 2008. Effect of subsurface drip irrigation on onion yield.10 June 2008 / Published online: 27 June 2008. SpringerVerlag 2008, 27(2), 97-108.

Pereira L.S., Perrier, A.; Allen, R.G. and Alves I. 1996. Evapotranspiration : Review of concepts and future trends. Evapotranspiration and irrigation scheduling. Proceedings of the international conference. American sociaty of agricultural engineers. San Antonio, Texas, USA, November 3-6, 109-115.

Rafea A. and Shallan K. 2011. "Using expert system as a training tool," the agriculture sector in Egypt. Expert System with Application, 11, 343-349.

Storm H., Heckelei T. and Heidecke C. 2011. Estimating irrigation water demand in the Moroccan Drâa Valley using contingent valuation. J. of Environmental Management 92, 28032809.

Tripathi K.P. 2011. "A Review on Knowledgebased Expert System: Concept and Architecture," IJCA Special Issue on Artificial Intelligence Techniques. Novel Approaches \& Practical Applications, 4, 19-23. 


\begin{tabular}{|c|c|c|}
\hline$\sqrt{8}$ & 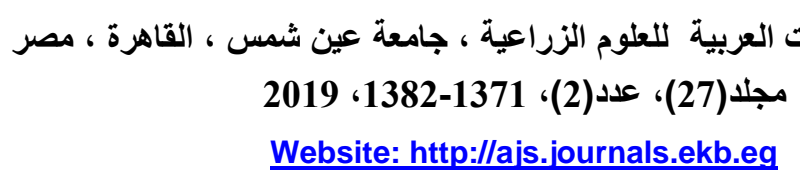 & 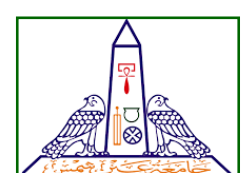 \\
\hline 38 & & \\
\hline
\end{tabular}

نظام خبير لإدارة نظام الرى المحورى لإنتاج محصول البطاطس في الأراضى حديثة الأستصلاح

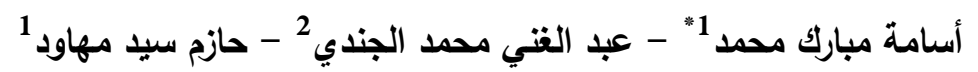

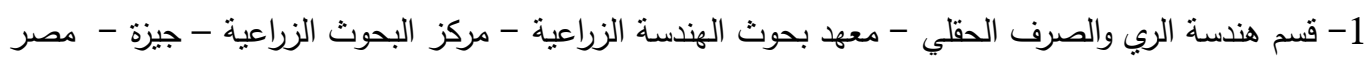

$$
\begin{aligned}
& \text { 2- قسم الهندة الزراعية - كلية الزراعة- جامعة عين شمس - ص.ب. } 68 \text { - حدائق شبرا } 11241 \text { - القاهرة - } \\
& \text { مصر }
\end{aligned}
$$

[113]

*Corresponding author: osamamobarakmohamed@gamil.com

Received 22 May, 2019

Accepted 19 June, 2019

الري. نم التحقق من صحتها من خلال إجراء تجربة في

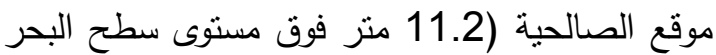

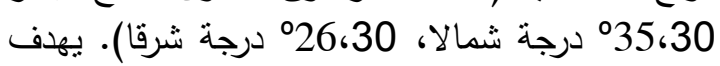

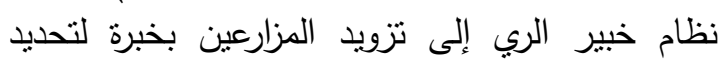
كميات المياه اللازمة في الوقت المئ المحدد وفقامًا لمنطلبات

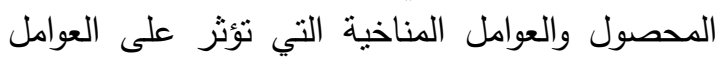

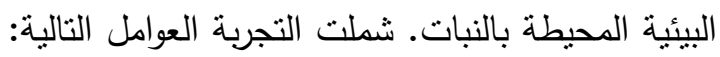

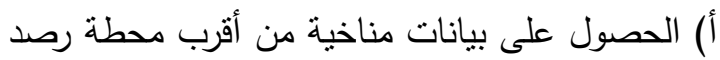

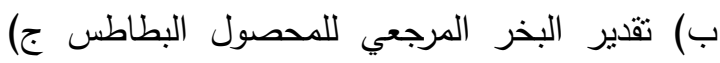

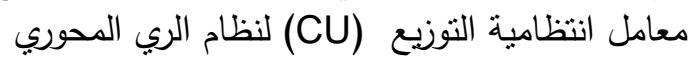

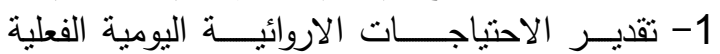
للفحصول (ETa) باستخدام معامل المحصول. لإنئ.

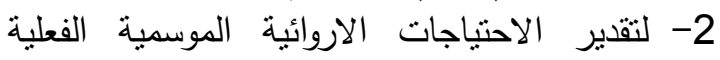

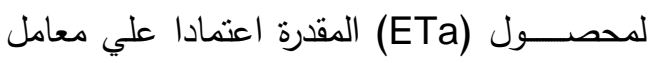

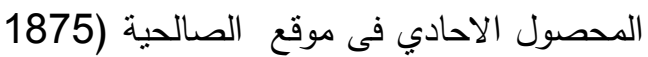
مج م / فدان / الموسم).

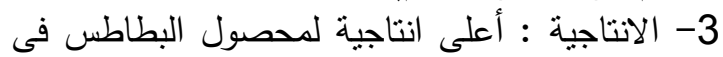

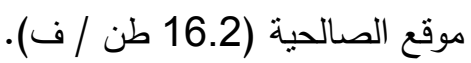

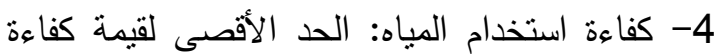
استخدام المياه في الصالحية (75. كجم م - كم).

الكلمات الدالة: الصالحية، البخر نتح المرجعي،

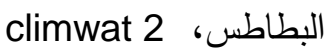

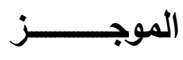

تعتبر كفاءة استخدام مياه الري فى جدولة الري أمرًا

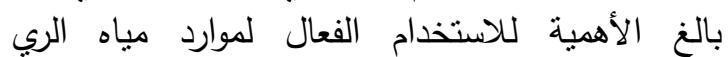

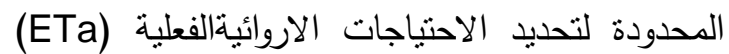

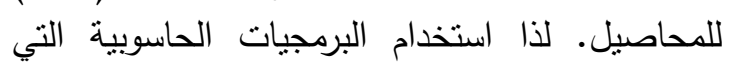
تعتمد علي الذكاء الاصطناعي كالنظم الخبيره اصبح

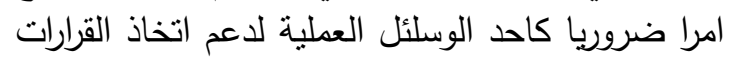

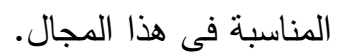
أهداف هذه الدراسة (1) تصميم و تقييم نظام خبير

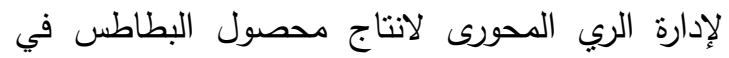

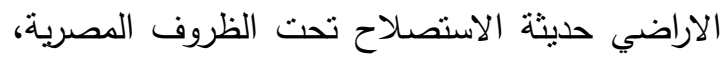

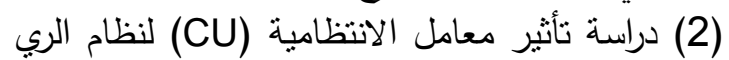

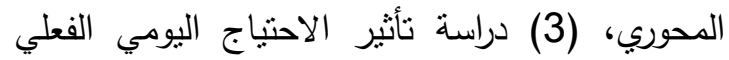
للنبات (ETa) على زيادة المحصول وتحسين كفاءة الثية

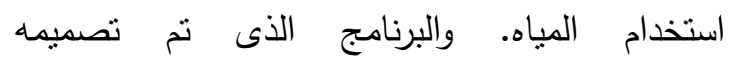
واستخدامهCPISM-ES (نظام إدارة نظام الريام المحوري - نظام خبير) عبارة عن أكواد ونم تجميعها

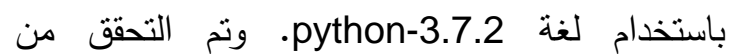
البرنامج باستخدام برامج برمجية جاهزة للاستخدام (climwat و لتقدير التبخر المرجعي (cropwat-8) اليومي وجدول بيانات باسم (FAO56Ax8.xIs) تم تقديمه بواسطة FAO-56 لتقدير معايير إدارة مياه 